\title{
INDIVIDUAL EDUCATION PROGRAM KAITANNYA DENGAN DIFFERENTIATED ASSESSMENT: STRATEGI MENGAKOMODIR SISWA BERKEBUTUHAN KHUSUS DI SEKOLAH UMUM
}

\author{
Dina Sekar Vusparatih \\ Jurusan Marketing Communication, Fakultas Komunikasi dan Ekonomi, BINUS University \\ Jln. K.H. Syahdan No. 9, Palmerah, Jakarta Barat 11480 \\ dinasekar@yahoo.com
}

\begin{abstract}
Individual Education Program (IEP) is a plan made by a team consists of parents, teachers, and other school elements. The purpose of IEP is to help students reach expected academic target. IEP is designed for students in special needs that not only defined academic target but also the methods for reaching the target. The article explains the stages in defining IEP. The primary purpose of IEP is to give the same chance for students with special needs to have standard and public school education for other normal students. Through public schools, the students with special needs could interact and socialize with other students.
\end{abstract}

Keywords: Individual Education Program (IEP), students with social needs

\begin{abstract}
ABSTRAK
Individual Education Program (IEP) adalah sebuah rencana yang dibuat oleh sebuah tim yang terdiri dari orang tua, guru dan pihak sekolah lainnya. Tujuan dari IEP adalah untuk membantu siswa mencapai target akademik yang telah ditetapkan. IEP dirancang untuk siswa berkebutuhan khusus yang tidak hanya menentukan target akademik tetapi juga metode untuk mencapai target tersebut. Artikel membahas langkah-langkah dalam menentukan IEP. Hal utama yang ingin dicapai dari IEP adalah memberikan kesempatan yang sama bagi siswa berkebutuhan khusus mengecap pendidikan di sekolah yang standard dan umum untuk siswa normal lainnya. Melalui sekolah umum, siswa berkebutuhan khusus dapat berinteraksi dan bersosialisasi dengan siswa mana pun.
\end{abstract}

Kata kunci: Individual Education Program (IEP), siswa berkebutuhan khusus 


\section{PENDAHULUAN}

Pendidikan adalah hak semua orang. Dari anak batita hingga sudah menjadi kakek nenek sekalipun masih berhak akan pendidikan. Pergi ke sekolah dan menimba ilmu adalah kegiatan yang tidak akan pernah lekang oleh waktu. Belajar, belajar dan terus belajar sampai ajal menghampiri. Namun pertanyaan berikutnya adalah apakah pendidikan yang tersedia sudah dapat mengakomodir kebutuhan setiap individu? Apakah pendidikan yang tersedia dapat terjangkau oleh siapa saja yang masih ingin sekolah?

Pendidikan dari tingkat KB sampai dengan perguruan tinggi sudah tersedia di setiap negara meski untuk pemerataan ketersediaan di tiap tingkatan masih bervariasi. Bahkan pendidikan untuk anak-anak yang berkebutuhan khusus pun sudah tersedia sebagaimana contohnya di Indonesia. Berdasarkan Undang Undang Dasar 1945 pasal 31 ayat 1 dan Undang- Undang Nomor 20 tahun 2003 tentang Sistem Pendidikan Nasional dapat disimpulkan bahwa negara memberikan jaminan sepenuhnya kepada anak berkebutuhan khusus untuk memperoleh layanan pendidikan yang bermutu. Hal ini menunjukkan bahwa anak berkebutuhan khusus atau anak luar biasa berhak pula memperoleh kesempatan yang sama dengan anak lainnya dalam pendidikan.

Pada saat ini, layanan pendidikan bagi anak berkebutuhan khusus di Indonesia disediakan melalui tiga macam lembaga pendidikan yaitu, Sekolah Luar Biasa (SLB), Sekolah Dasar Luar Biasa (SDLB), dan Pendidikan Terpadu. SLB, merupakan lembaga pendidikan khusus tertua yang menampung anak dengan jenis kelainan yang sama sehingga SLB yang satu dengan yang lain akan berbeda tergantung dengan jenis kelainan. Oleh karena itu, kita akan temukan SLB untuk anak dengan hambatan penglihatan (tunanetra), SLB untuk anak dengan hambatan pendengaran (tunarungu), SLB untuk anak dengan hambatan berpikir/kecerdasan (tunagrahita), SLB untuk anak dengan hambatan fisik dan motorik (tunadaksa), SLB untuk anak dengan hambatan emosi dan perilaku (tunalaras), dan SLB untuk anak dengan hambatan majemuk (tunaganda). Sedangkan SDLB menampung berbagai jenis anak berkebutuhan khusus dalam satu sekolah. Sementara lembaga pendidikan ketiga yang juga menampung anak berkebutuhan khusus adalah pendidikan terpadu ayaitu sekolah reguler yang juga menampung anak berkebutuhan khusus, dengan kurikulum, guru, sarana pengajaran, dan kegiatan belajar mengajar yang sama.

Untuk jenis lembaga pendidikan ketiga ini yaitu sekolah umum yang mau menerima anakanak berkebutuhan khusus, masih sulit ditemui apalagi sekolah-sekolah milik pemerintah. Sekolah negeri masih menjadikan nilai sebagai tolok ukur seorang anak layak diterima atau tidak. Kemampuan akademis adalah perhatian utama yang seringkali menjadi kriteria penilaian seleksi penerimaan siswa baru. Sementara kemampuan akademis yang setara dengan anak-anak normal merupakan masalah utama bagi anak-anak berkebutuhan khusus ini. Lalu bagaimana anak-anak ini mendapatkan pendidikan yang mau memahami kondisi mereka?

Perkembangan saat ini menunjukkan semakin tingginya tingkat pendidikan masyarakat seiring sejalan dengan meningkatnya pemahaman masyarakat tentang arti pendidikan terhadap masa depan seseorang. Hal ini juga berlaku bagi para orang tua yang memiliki anak-anak berkebutuhan khusus. Mereka lebih menginginkan anak-anak mereka sekolah di sekolah umum bukan di sekolah khusus yang justru semakin mengisolasi dan membedakan anak-anak mereka dari anak-anak normal. Tentu saja dengan nilai dan kemampuan akademis yang menjadi tolok ukur utama penerimaan siswa baru di sekolah negeri menjadi kendala terbesar. Jangankan untuk pencapaian akademis, untuk pencapaian kemampuan dari sisi sosialisasi maupun kemandirian saja, anak-anak berkebutuhan khusus memerlukan waktu yang cukup lama. 
Namun sebenarnya orang tua yang memiliki anak-anak dengan kebutuhan khusus ini sudah tidak perlu khawatir lagi karena kekhawatiran mereka sudah dideteksi oleh beberapa ahli pendidikan yang kemudian memutuskan untuk membuat lembaga pendidikan formal yang bersifat inklusif. Pada saat ini sudah banyak bermunculannya sekolah-sekolah swasta yang mau menerima anak-anak berkebutuhan khusus dari tingkatan Kelompok Bermain (KB) sampai dengan Sekolah Menengah Atas (SMA).

Dengan menggunakan konsep inklusif, sekolah-sekolah tersebut selain membuka diri untuk umum juga membuka diri untuk anak berkebutuhan khusus. Sekolah menyediakan berbagai hal yang mendukung pendidikan untuk anak-anak ini seperti dari SDM yaitu guru-guru, therapis, dan fasilitas. Untuk poin terakhir, masih minim jumlahnya karena biasanya hanya sekolah yang khusus pendidikan luar biasa saja yang menyediakan fasilitias lengkap. Tapi apakah sekolah yang bersedia membuka diri untuk semua anak, sudah mempunyai persiapan yang juga lengkap dan dapat mengakomodir semua kebutuhan siswa? Hal inilah yang menjadi perhatian utama pada perkembangan konsep sekolah yang berani menyatakan diri sebagai sekolah inklusif. Fenomena semakin banyaknya sekolah inklusif justru mengkhawatirkan karena ternyata tidak semua dari sekolah tersebut siap dalam menghadapi berbagai dinamika yang akan terjadi ketika menjalankan pendidikan untuk anak-anak pada umumnya dan anakanak berkebutuhan khusus pada waktu bersamaan dan lokasi yang sama.

Berdasarkan observasi penulis, tidak sedikit sekolah yang belum memiliki konsep yang jelas dalam mendidik anak-anak berkebutuhan khusus. Menyediakan seorang guru pendamping atau biasa disebut shadow tidaklah cukup jika pemahaman bahwa anak-anak ini bisa diperlakukan dengan menggunakan kurikulum yang juga diaplikasikan pada anak-anak lain pada umumnya, masih melekat di pemikiran para tenaga pendidik. Hasil akhirnya justru akan menjadi kontra produktif pada anak dan memberikan beban moral dan materil yang lebih berat pada orang tua. Tidak mustahil juga jika salah dalam pembuatan program maka anak-anak berkebutuhan khusus ini malah menjadi siswa aneh di kelas yang kemudian menjadi siswa minoritas yang kian terpojok. Padahal keberadaan mereka di kelas pun sudah menjadi minoritas. Minoritas yang semakin tersudut dan terisolasi. Sementara tujuan awal orang tua mempercayai sekolah tersebut untuk anak-anak mereka justru agar mereka terbiasa dengan dunia yang sesungguhnya dan mampu bersosialisasi dengan masyarakat pada umumnya dengan apapun kondisi mereka itu.

Oleh karena itulah, sekolah yang menyatakan diri terbuka untuk semua anak seharusnya juga sudah siap dengan segala kurikulum dan program untuk semua anak ini. Jika kurikulum KTSP telah tersedia untuk anak-anak pada umumnya, lalu kurikulum dan program apa yang sekolah tersebut telah siapkan untuk anak-anak berkebutuhan khusus. Biasanya, trend sekolah swasta saat ini adalah mengkolaborasi kurikulum KTSP dengan berbagai kurikulum lainnya, sebagai usaha membangun karakter sekolah yang mampu "menjual" sekolah dalam menghadapi kerasnya persaingan antar sekolah-sekolah swasta yang kian menjamur. Konsep sekolah Nasional plus, sekolah Islam terpadu, sekolah alam, sekolah yang juga menggunakan kurikulum Cambridge, atau bahkan sekolah IB, sudah banyak menjadi senjata tambahan untuk memperkaya kurikulum dan program sekaligus usaha positioning sekolah. Tetapi kurikulum dan program untuk anak-anak berkebutuhan khusus seringkali diletakkan sebagai prioritas terakhir atau parahnya lagi dibahas sambil jalan alias trial and error.

Tentu saja jika fenomena ini banyak terjadi, sungguh sangat berbahaya dan merugikan tidak hanya bagi anak-anak berkebutuhan khusus ini tetapi juga bagi orang tua mereka. Mendapatkan fakta memiliki anak yang berbeda dari anak lain pada umumnya saja sudah menjadi cobaan berat yang harus dihadapi, ditambah lagi dengan fakta bahwa ternyata mereka telah salah memilih sekolah. Untuk mengatasi hal ini, sekolah yang berani menyatakan diri inklusif, sudah seharusnya juga telah menyiapkan berbagai hal untuk mendukung kelancaran pendidikan bagi anak-anak berkebutuhan khusus ini. Tidak hanya guru-gurunya, tetapi juga kurikulum dan program. Yang dimaksud dengan kurikulum disini termasuk didalamnya proses penilaian yang merupakan tolok ukur sebuah kurikulum berhasil dicapai atau tidak. 
Merancang rencana dan proses penilaian bagi anak-anak berkebutuhan khusus yang menjalani kegiatan belajar di sekolah umum bukan pekerjaan mudah. Sebagaimana telah disebutkan di awal bahwa pada saat ini nilai dalam format angka masih menjadi tolok ukur utama pencapaian keberhasilan seorang siswa untuk melanjutkan pendidikan ke jenjang yang lebih tinggi lagi. Sementara untuk mengikuti dan memenuhi target materi sesuai kurikulum saja untuk anak-anak ini tidaklah mudah, apalagi mencapai nilai standar sebagaimana berlaku bagi anak-anak pada umumnya. Disinilah peran tenaga pendidik sangat penting karena diperlukan sebuah perencanaan penilaian yang bisa mengakomodir anak-anak berkebutuhan khusus ini. Tenaga pendidik yang dimaksud tidak hanya guru tetapi juga kepala sekolah dan elemen sekolah lainnya. Namun yang paling penting adalah peran orang tua sebagai tenaga pendidik seumur hidup anak tersebut.

\section{PEMBAHASAN}

\section{Strategi Menilai}

Menurut Chapman \& King (2005), guru yang efektif secara strategi adalah guru yang memilih alat penilaian yang sesuai untuk setiap situasi pembelajaran. Sebagaimana analogi yang mereka gunakan yaitu seorang tukang kayu yang menggunakan palu untuk memukul paku dan menggunakan gergaji untuk memotong kayu. Analogi ini mencoba menggambarkan bahwa seorang tukang kayu pun harus menggunakan alat yang sesuai untuk mencapai apa yang ia inginkan. Bagaimana jadinya jika ia menggunakan palu untuk memotong kayu atau sebaliknya menggunakan gergaji untuk memukul paku. Ada kemungkinan ia berhasil memotong kayu dengan palu tetapi berapa lama waktu yang ia butuhkan? Apakah sama dengan ketika ia menggunakan gergaji? Bagaimana hasilnya? Apakah lebih baik dengan palu? Bisa dipastikan ia akan membutuhkan waktu lebih lama ditambah lagi dengan usaha yang begitu besar yaitu ia harus berpikir keras menggunakan metode yang pas mengingat bentuk dari palu tidak dirancang untuk memotong tetapi dirancang untuk memukul. Begitu juga jika ia memaksa untuk memukul paku dengan gergaji. Ada kemungkinan ia berhasil menancapkan paku ke tembok dengan gergaji namun bisa dipastikan ia membutuhkan waktu lebih lama dan kemungkinan tangannya terluka karena terkena gerigi tajam dari gergaji. Tentu saja hal ini terjadi karena gergaji tidak dirancang untuk memukul dan tidak dirancang berbentuk tumpul seperti palu melainkan tajam, sesuai dengan kegunaannya yaitu memotong kayu. Ketajaman gerigi gergaji pun sudah dirancang untuk tekstur kayu yang keras sehingga akan terasa sangat tajam jika terkena kulit manusia yang teksturnya jauh lebih lembut dari kayu.

Masih menggunakan analogi si tukang kayu, pada akhirnya ia akan memilih menggunakan alat yang sesuai dengan tujuan yang ingin dicapai. Dalam usaha memilih alat ini, tukang kayu akan menggunakan kemahiran dan pengalamannya. Jika seorang tukang kayu saja mampu memilih alat yang tepat, apalagi seorang guru yang jauh lebih terpelajar. Sudah seharusnya seorang guru mampu memilih alat penilaian yang tepat untuk menilai kemampuan siswanya yang berbeda-beda. Chapman \& King (2005), menjelaskan secara detil tentang diperlukannya penilaian yang berbeda-beda atau mereka menyebutnya Differentiated Assessment.

Menurut Chapman \& King (2005), Differentiated Assessment adalah proses yang berkelanjutan dimana seorang guru mengumpulkan data sebelum, selama, dan sesudah sebuah instruksi diberikan dari berbagai sumber, yang bertujuan untuk mengindetifikasi kekuatan dan kebutuhan siswanya. Definisi ini terlahir dari pemikiran bahwa setiap siswa mempunyai pengetahuan dan kemampuan yang berbeda-beda. Kedua poin ini sangat mempengaruhi cara dan kecepatan proses seorang siswa belajar, dan cara dan kecepatan seorang siswa mengaitkan pengetahuan yang ia miliki sebelumnya dan pemahamannya. Dari penjelasan ini, dapat disimpulkan bahwa seorang guru harus terus menerus menilai siswanya sehingga ia dapat mengetahui sektor dari siswa yang harus diasah terus potensinya dan sektor yang harus ditingkatkan. Kekuatan dan kekurangan setiap siswa tentu saja berbeda-beda, oleh karena itulah penilaian harus berjalan berkelanjutan. Jika pada sekolah umum, 
penilaian yang berkelanjutan ini bisa dibagi kedalam beberapa macam penilaian yaitu formatif dan sumatif.

Pengaplikasian konsep differentiated assessment harus dimulai pada tahap perencanaan kurikulum. Ketika merancang kurikulum, seorang guru akan membuat perencanaan mulai dari pemetaan konsep berdasarkan kompetensi yang ingin dicapai, kemudian memetakan kurikulum untuk 1 tahun ajaran ke dalam 2 semester lalu membaginya kembali ke tiap minggu dan terakhir perencanaan sampai pada tahap pertemuan di setiap minggunya. Perencaan kegiatan di setiap pertemuan harus meliputi materi pelajaran yang akan diajar, tujuan pertemuan, indikator pencapaian, waktu yang diperlukan, kegiatan yang akan dilakukan, dan bentuk serta alat penilaian yang akan digunakan. Sekali lagi, proses penilaian diperlukan untuk mengukur apakah siswa telah mencapai target tujuan pembelajaran pada pertemuan tersebut. Oleh karena itu, perencanaan memilih alat penilaian harus sudah dimulai ketika kurikulum dirancang. Dapat dipastikan bahwa dalam tiap pertemuan akan ada bentuk penilaian yang berbeda karena target pencapaian yang ditetapkan pun berbeda mengingat kemampuan siswa dalam sebuah kelas berbeda-beda.

Menurut Chapman \& King (2005), differentiated assessment diperlukan untuk mengumpulkan informasi tentang siswa karena setiap siswa itu unik pada hal-hal, seperti: pengetahuan dasar; latar belakang dan pengalaman sebelumnya; motivasi; sikap terhadap topik atau mata pelajaran yang sedang diberikan; emosi dan keinginan; gaya belajar; multiple intelligences; kemampuan, minat, dan bakat.

Dengan mempertimbangkan hal-hal unik dari setiap siswa maka guru dapat mempunyai bekal untuk melihat kekuatan dan poin apa yang harus ditingkatkan dari setiap siswa. Untuk mengukur kekuatan dan kebutuhan yang perlu ditingkatkan dari siswa dimana setiap siswa pasti berbeda-beda maka guru perlu memilih alat penilaian yang berbeda pula untuk setiap siswa. Jika guru dapat memilih alat penilaian yang disesuaikan dengan tujuan yang akan dicapai dan kebutuhan siswa maka menurut Chapman \& King (2005), guru tersebut dapat menyediakan lebih banyak lagi arahan yang mendalam, mengulang pelajaran sebelumnya, rencana selanjutnya, membuat rencana yang spesifik, serta melibatkan siswa pada kegiatan pengembangan diri yang sesuai dengan minatnya

\section{Penilaian pada Anak Berkebutuhan Khusus}

Melanjutkan pemahaman differentiated assessment kaitannya dengan penilaian terhadap anak berkebutuhan khusus, marilah kita coba merunut dari tahap yang paling awal. Untuk merencanakan proses penilaian pada siswa, seorang guru awalnya akan membuat pemetaan kurikulum seperti dalam bentuk silabus yang bisa dibuat per semester atau per tahun ajaran. Setelah silabus selesai, guru akan menjabarkan lagi ke dalam program per-minggu dan per-petemuan. Pada tahap inilah, guru akan membuat program yang dilengkapi dengan alat penilaian yang disesuaikan dengan kebutuhan siswa dan target pencapaian guru per pertemuan.

Ketika seorang siswa memang telah diketahui mempunyai ketidak mampuan baik akademis dan non akademis sebagaimana siswa normal, maka sudah menjadi kewajiban seorang guru untuk membuat program khusus. Perencanaan program khusus ini ditujukan untuk memudahkan guru dalam proses penilaian dan perencanaan program selanjutnya. Secara umum, menurut Taylor, Smiley, \& Richards, 2009, program untuk anak/siswa berkebutuhan khusus terbagi menjadi dua yaitu: (1) IFSP (Individual Family Service Plan), diberikan pada anak-anak di usia setelah lahir sampai dengan 2 tahun. Dapat disimpulkan IFSP ini diberlakukan pada anak-anak yang belum sekolah dan lebih cenderung dilakukan oleh keluarga dan terapis; (2) IEP (Individual Education Program), diberikan pada anak-anak di usia 3-21 tahun. Berbeda dengan IFSP, IEP memang ditujukan untuk anak yang sudah sekolah dan dapat dipastikan tidak hanya orang tua namun guru mempunyai peanan penting dalam pembuatan program ini. Dalam merancang IEP banyak hal yang perlu diperhatikan. 


\section{Definisi IEP}

Menurut Taylor, Smoley \& Richards (2009), IEP adalah sebuah perencanaan program pendidikan siswa yang dirancang oleh sebuah tim. Ditilik dari definisi tersebut, boleh dikatakan bahwa pembuatan IEP ini tidaklah dibuat sendiri oleh guru atau pun orang tua saja tapi sebuah tim. Mengapa tim? Pendidikan di sekolah dijalankan tidak hanya oleh guru tetapi juga seluruh elemen sekolah dan keluarga. Elemen sekolah terdiri dari guru kelas, guru bidang studi, kepala sekolah, bahkan staf admin dan kebersihan sekolah. Semua elemen ini harus diikut sertakan ke dalam perencanaan IEP. Tentu saja masing-masing elemen akan mempunyai presentase peranan yang berbeda-beda. Dari unsur keluarga pun memegang peranan penting di mana terdiri tidak hanya orang tua tetapi saudara kandung siswa dan siapa saja yang tinggal di dalam rumah siswa yang bersangkutan.

IEP dibuat oleh sebuah tim tetapi berlaku hanya untuk 1 siswa. Hal ini mengingat kemampuan dan kondisi dari siswa satu dan yang lain berbeda-beda. IEP sendiri baru bisa mulai dirancang ketika kurikulum inti dari sekolah sudah tersedia. Kurikulum inti adalah kurikulum yang berlaku untuk siswa pada umumnya. Setelah kurikulum inti sudah tersedia, barulah proses pembuatan IEP dapat dilaksanakan. Mengapa demikian? Perencanaan program IEP merupakan penjabaran dari kurikulum inti lalu disesuaikan dengan kekuatan dan kebutuhan masing-masing siswa.

\section{Tim Pembuat IEP}

Jika sebelumnya telah dijelaskan bahwa perancang IEP adalah sebuah tim, siapa sajakah yang seharusnya ada dalam tim tersebut. Guru kelas, guru pendamping (shadow) dan orang tua adalah bagian dari tim yang paling penting. Namun kehadiran seorang staf bagian kurikulum sekolah dan therapis yang memang pakar dalam hal masalah anak-anak berkebutuhan khusus ini, juga cukup penting. Masing-masing anggota tim mempunyai kontribusi dalam perencaan IEP ini. Guru kelas adalah orang yang paling tahu tentang perkembangan siswa di dalam kelas baik secara akademis dan non akademis. Sementara orang tua adalah anggota tim yang paling mengetahui tentang sikap dan perkembangan siswa selama di rumah dan di masyarakat sekitarnya. Guru pendamping dan terapis kurang lebih mempunyai peranan yang hampir sama dalam tim ini. Keduanya mempunyai keahlian dan ilmu yang sama-sama fokus pada anak-anak berkebutuhan khusus namun guru pendamping berkonsentrasi pada pengaplikasian IEP secara individu, sedangkan therapis lebih kepada keterlibatannya pada hasil dan evaluasi pada setiap akhir dan awalan sebuah IEP. Staf kurikulum sekolah berperan dalam membantu menjabarkan kurikulum sekolah, target pencapaian dan standar penilaian yang sekolah harapkan dari siswa. Melalui informasi dari staf kurikulum, anggota tim yang lain dapat mengetahui target pencapaian standar yang harus dicapai seorang siswa untuk dinyatakan mampu memahami materi dan dinyatakan lulus atau naik kelas.

Pada tahap ini, biasanya guru kelas, shadow dan therapis akan membicarakan target pencapaian siswa apakah mampu mengikuti target layaknya siswa normal. Jika ternyata siswa dinilai tidak mampu mengikuti pencapaian standar dalam waktu yang sama dengan siswa lainnya maka ketiga anggota tersebut akan membuat program IEP di mana persetujuan orang tua sangatlah penting. Penurunan target pencapaian atau penentuan kebutuhan waktu yang lebih lama untuk mencapai target pencapaian tertentu, akan sangat berpengaruh karena kalender akademik tiap tahun ajaran tidak bisa diperpanjang. Di sinilah peranan orang tua menjadi sangat penting. Ada orang tua yang mau menerima kenyataan tersebut namun ada pula yang tidak terima. Di sinilah dibutuhkan kordinasi dan semangat kerjasama karena IEP yang sudah disepakati harus benar-benar dijalankan secara komitmen oleh setiap anggota tim.

Hal utama yang penting dalam sebuah tim IEP adalah semangat kerjasama dan kesadaran bahwa setiap anggota mempunyai kesetaraan. Berhasil atau gagalnya IEP adalah hasil tim dan dipertanggung jawabkan oleh tim. Ketika proses diskusi merancang IEP, setiap anggota harus dan 
selalu berpikir bahwa semua kerja keras menghasilkan IEP adalah untuk kebaikan siswa bukan untuk guru atau pun obsesi orang tua. It is all about the student.

\section{Tujuan Pembuatan IEP}

Pembuatan IEP pada intinya ditujukan untuk 3 hal yaitu: (1) melalui program ini siswa diharapkan dapat mengikuti sekolah umum dengan berbagai kegiatannya dan berbagai variasi siswanya serta kondisi yang ada; (2) melalui program ini siswa diharapkan dapat mengikuti sistem penilaian yang sesuai standar sekolah; (3) melalui program ini siswa diharapkan dapat berinteraksi dan bersosialisasi dengan siswa normal lainnya.

Dari ketiga tujuan tersebut, jelas sekali bahwa tujuan dibuatnya IEP adalah agar siswa berkebutuhan khusus dapat bersekolah di sekolah umum dengan segala konsekwensi yang ada. Target kurikulum, target pencapaian, standar nilai dan mampu berinteraksi dengan siswa normal. Tetapi untuk mencapai semua tujuan itu tidaklah mudah. Karena seringkali untuk mencapai 1 tujuan saja membutuhkan waktu yang cukup lama dan bahkan harus mengorbankan pencapaian tujuan yang lainnya. Untuk siswa berkebutuhan khusus pada kondisi yang cukup parah, bisa jadi tujuan utama IEP adalah untuk sosialisasi dan interaksi terlebih dahulu karena tidak mungkin menempatkan target pencapaian akademis menjadi yang utama sementara siswa mengalami masalah dalam bersosialisasi. Pada kondisi seperti itu, IEP menjadi sangat dibutuhkan karena kurikulum yang berlaku untuk siswa umum mempunyai target waktu dan tes yang nantinya akan menjadi tolok ukur standar dalam mengukur pemahaman siswa. Sementara pada kasus siswa berkebutuhan khusus, siswa membutuhkan waktu lebih lama untuk memahami materi bahkan bisa jadi siswa tersebut membutuhkan waktu untuk belajar bersosialisasi dengan guru kelasnya atau teman-temannya terlebih dahulu.

Pada prakteknya, dari ketiga tujuan tersebut, tujuan nomer 3 yang biasanya menjadi prioritas. Berangkat dari pemikiran bahwa orang tua lebih berharap jika anaknya bisa hidup secara mandiri di masyarakat. Hidup mandiri memang menjadi momok bagi anak berkebutuhan khusus karena hampir di setiap lini dari kegiatan hidupnya, mereka membutuhkan bantuan dari orang lain. Tentu saja orang tua selalu berpikir bagaimana jika mereka sudah tidak lagi hidup di dunia. Siapa yang akan membantu anak mereka kecuali anak itu sendiri. Itulah kenapa bagi banyak kasus anak berkebutuhan khusus yang bersekolah di sekolah umum, tujuan akhirnya adalah siswa mampu hidup mandiri di masyarakat, mampu bersosialisasi dan berinteraksi dengan normal.

\section{Proses Pembuatan IEP}

Tim pembuat IEP harus memahami betul proses pembuatan IEP karena IEP bisa diibaratkan kurikulum utama bagi para siswa berkebutuhan khusus ini. Perbedaan penentuan waktu pencapaian target dan standar nilai, membuat siswa ini akan mengalami kegiatan belajar mengajar yang berbeda dengan siswa normal lainnya. Presentase perbedaan kegiatan belajar antara siswa berkebutuhan khusus dengan siswa normal bervariasi tergantung pada kondisi siswa tersebut. Karena tujuan IEP adalah agar siswa ini tidak seperti orang aneh dan terisolasi dari yang lain maka prioritas utama adalah siswa ini diharapkan selalu mengikuti semua kegiatan sekolah bersama dengan siswa yang lain. Oleh karena itu, pada proses pembuatan IEP, tim wajib mempertimbangkan betul faktor-faktor seperti target pencapaian, waktu pencapaian, dan batas waktu berakhirnya program yang disesuaikan dengan durasi tahun ajaran sesuai dengan kalender akademik sekolah. Hal ini dilakukan agar persentase perbedaan kegiatan antara siswa berkebutuhan khusus dengan siswa lainnya tidak terlalu besar. Semakin lama siswa melakukan kegiatan bersama siswa normal maka semakin bagus untuk perkembangan kemampuannya berinteraksi dan bersosialisasi. 
Alur pembuatan IEP, idealnya seperti pada Gambar 1.

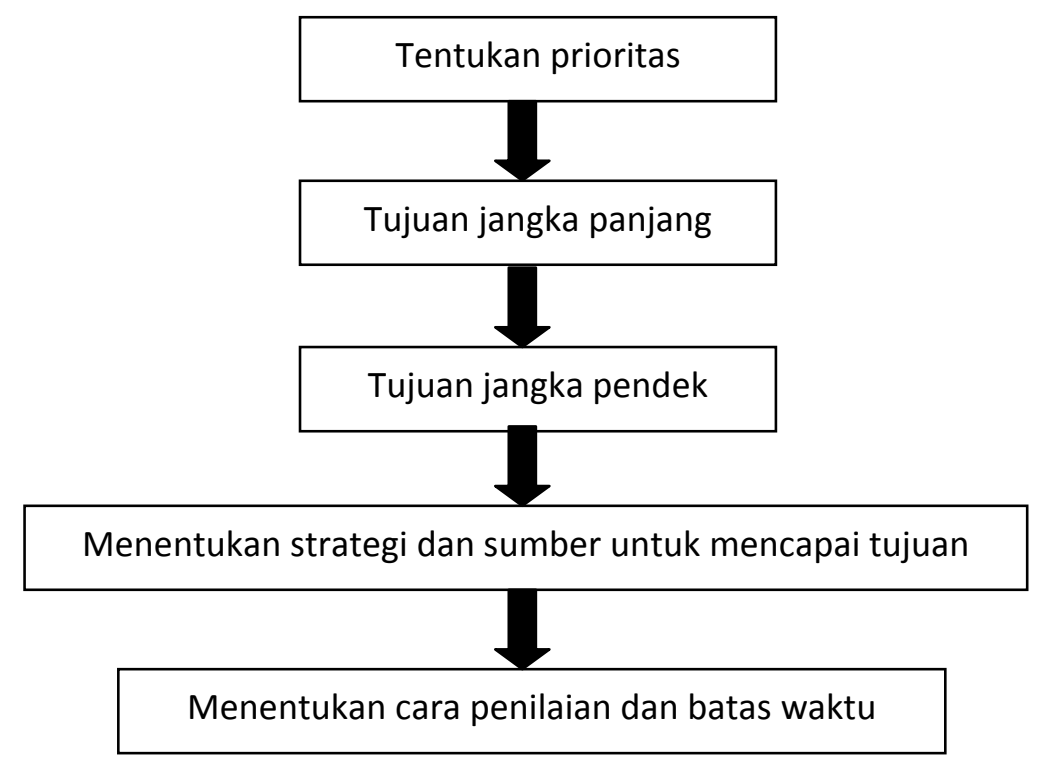

Gambar 1 Alur pembuatan IEP

Merunut dari skema tersebut, dapat dilihat bahwa skala prioritas serta penentuan cara menilai dan batas waktu adalah strategi paling jitu dalam memulai pembuatan program IEP, sekaligus poin paling penting dalam keberlangsungan sebuah IEP dan kemajuan perkembangan siswa. Tentukan dulu prioritas utama, baru kemudian membahas tujuan. Prioritas utama untuk siswa berkebutuhan khusus ini bukanlah mengenal angka 1-10 dalam pelajaran Matematika sebagaimana layaknya siswa SD kelas 1 pada awal masuk sekolah, atau membaca dua suku kata dalam pelajaran Bahasa Indonesia. Prioritas utama siswa ini pada awal-awal tahun ajaran biasanya mengenal lingkungan sekolah, mengenal guru kelasnya, mengenal beberapa teman kelasnya (dipilih beberapa saja), mengenal karyawan kebersihan sekolah, mengenal petugas keamanan sekolah, mengenal petugas kantin, dan mengenal lingkungan kelasnya (dimana meja guru, dimana loker untuk meletakkan tas, dan dimana kursi untuk dia duduk). Jika dibaca sekilas, tampaknya prioritas utama siswa berkebutuhan khusus ini hampir sama dengan siswa normal. Namun pada prakteknya, jika siswa normal butuh seminggu untuk mengenal lingkungan baru sekolahnya, tapi siswa berkebutuhan khusus memerlukan waktu lebih lama. Untuk mengenal siapa yang menjadi guru kelasnya saja perlu seminggu (menghafal nama, mengingat wajah, atau sekedar menegur dan menyapa). Belum lagi guru bidang studi atau teman kelasnya. Durasi waktu seminggu pun bisa jadi berbeda lagi dengan kondisi siswa berkebutuhan khusus lainnya tergantung pada hasil diagnosa. Siswa yang menderita autis memerlukan waktu lebih lama dibandingkan siswa yang menderita hiperaktif.

Penjelasan di atas adalah salah satu contoh bentuk prioritas bagi siswa yang berkebutuhan khusus ini. Jelas terlihat perbedaannya jika coba dibandingkan dengan perencanaan program untuk siswa normal yang berbasis KTSP. Inilah kenapa sebagaimana dijelaskan sebelumnya, IEP ini adalah kunci keberhasilan jalannya kegiatan belajar siswa berkebutuhan khusus di sekolah umum. Karena sangat mungkin penentuan tujuan jangka panjang sampai menjadi tujuan jangka pendek, strategi, cara penilaian dan batas waktu, berbeda sekali dengan siswa normal lainnya. Tujuan jangka panjang seorang siswa berkebutuhan khusus mungkin saja hanya "mampu berkomunikasi dengan 5 teman kelasnya untuk konteks bertegus sapa yang tidak lebih dari 3 kalimat tanpa bantuan dan stimulus dari guru pendamping”. Tujuan jangka panjang ini mungkin saja diberi batas waktu 1 semester. Bayangkan sementara siswa normal kelas 1 dalam 1 semester harus mencapai target kurikulum tertentu seperti mampu mengenal angka 1-20, mampu menjumlah dan mengurangi angka tanpa menggunakan teknik, 
atau mampu membuat karangan sederhana dengan aplikasi huruf besar pada nama-nama kota dan hari. Disinilah program IEP berperan. Siswa berkebutuhan khusus satu sisi harus berusaha menyesuaikan diri dengan lingkungan namun di sisi lain harus juga mengikuti target kurikulum sekolah. IEP akan mengakomodir kebutuhan tercapainya target kurikulum sekolah tetapi biasanya akan disesuaikan dengan kondisi siswa. Differentiated Assessment akan diaplikasikan pada tahapan ini. Jika siswa normal dapat menggunakan tes tertulis untuk menilai pemahaman mereka, siswa berkebutuhan khusus mungkin menggunakan cara lain untuk menilai pemahaman mereka. Penentuan strategi dan cara menilai sebagaimana dijelaskan dalam skema, akan banyak mengadopsi strategi dari differentiated assessment ini.

\section{Komponen Utama dalam IEP}

Setelah memahami proses pembuatan IEP, langkah selanjutnya adalah memahami komponen apa saja yang seharusnya ada dalam IEP. Poin ini penting karena semua komponen yang terkandung dalam IEP saling mempengaruhi. Hilang 1 komponen berarti IEP tidak akan berjalan optimal. Komponen utama dalam IEP adalah identifikasi dan penilaian. Proses identifikasi pada proses pembuatan IEP saja menjadi langkah pertama, sehingga jelas ia menjadi komponen paling penting. Mengindentifikasi kekuatan dan kebutuhan siswa terlebih dahulu. Komponen identifikasi dan penilaian sama penting karena ketika mengindetifikasi, tim juga akan melihat hasil penilaian siswa sebelumnya, dengan tujuan untuk mengevaluasi strategi sebelumnya dan hal apa saja yang masih harus dilanjutkan.

Komponen berikutnya adalah perencanaan. Perencanaan ini meliputi merancang tujuan jangka panjang dan jangka pendek, strategi pencapaian, dan cara evaluasi. Komponen lain yang prosesnya berlangsung dalam komponen perencanaan adalah penentuan strategi pencapaian. Strategi pencapaian yang dimaksud adalah program support and implementation. Tim akan menentukan program apa saja yang akan dilakukan untuk mencapai tujuan baik jangka pendek maupun panjang. Program support disini adalah program yang diberlakukan untuk siswa berkebutuhan khusus saja. Kapan dan bagaimana serta efeknya terhadap siswa lain akan menjadi bahan pertimbangan dalam proses implementasi. Masih dalam proses pelaksanaan perencanan, komponen lainnya lagi yang terkandung di dalamnya adalah evaluasi. Komponen evaluasi akan memuat bagaimana tim terutama guru kelas dan guru pendamping akan mengevaluasi apakah program yang dijalankan telah berhasil membuat siswa mencapai target yang telah ditentukan pada komponen jangka pendek. Cara evaluasi ini ialah penentuan cara penilaian sekaligus refleksi dari para anggota tim tentang berjalannya program IEP dan keberhasilan atau kegagalan yang terjadi setelah batas waktu yang telah ditetapkan dalam IEP.

Komponen terakhir adalah report. Setelah IEP berjalan dan mencapai batas waktu yang telah ditentukan, tim harus segera membuat laporan hasil dari IEP. Komponen ini adalah cukup signifikan karena akan menjadi bahan untuk tim dalam membuat program IEP selanjutnya. Keberhasilan atau kegagalan atau pun setengah keberhasilan yang telah dicapai, akan memberi masukan positif untuk merancang IEP baru. Disinilah proses identifikasi akan bermulai kembali. Dapat disimpulkan, komponen-komponen IEP ini ibarat sebuat lingkaran yang akan terus berputar dan saling berkesinambungan. Jika 1 komponen hilang atau tidak optimal maka IEP juga tidak akan optimal jalannya.

\section{Aplikasi IEP}

Konsep sekolah inklusif yang dimaknai dengan menerima semua siswa dengan berbagai kondisi, tidak berarti berlaku sepenuhnya secara inklusif. Pada pelaksanaan IEP dikenal dua model konsep inklusif yaitu full dan partial. Partial di sini berarti sebagian waktu siswa di sekolah dijalankan di kelas yaitu dengan mengikuti semua kegiatan belajar di kelas bersama dengan siswa lain, dan sebagian waktunya lagi digunakan dengan belajar di ruang khusus hanya bersama guru pendamping dan dengan kegiatan belajar dan tujuan khusus sisw tersebut. Sementara full berarti seluruh waktu 
siswa di sekolah dijalankan di kelas bersama dengan siswa lainnya meskipun siswa menggunakan program IEP.

Penentuan menggunakan konsep full atau partial sangat berpengaruh terhadap perencanaan program IEP ini. Karena semua pilihan mempunyai efek samping yang berbeda-beda. Kehati-hatian sangat diperlukan karena bukan tidak mungkin malah akan menjadi kontra produktif. Namun satu hal yang perlu dipertimbangkan dengan seksama adalah apapun pilihan konsep inklusif ini, guru kelas dan guru pendamping sudah menyiapkan kondisi siswa baik siswa berkebutuhan khusus ini juga siswa lainnya yang berada di kelas. Kedua belah pihak harus disiapkan dulu menerima jalannya konsep full atau partial ini karena merekalah yang akan menerima dampak langsung. Misalnya siswa lain akan bertanya-tanya kenapa temannya (siswa berkebutuhan khusus) boleh meninggalkan kelas pada saatsaat tertentu sementara dia tidak boleh. Atau kenapa siswa berkebutuhan khusus ini diikutkan dalam kelompok mereka sementara mereka tahu kalau keberadaan siswa ini tidak akan membantu tugas yang diberikan. Hal ini akan menjadi sangat sensitif dan fatalnya bisa menimbulkan kecemburuan dan merasa ketidak adilan di siswa lain. Bukan tidak mungkin akan menimbulkan masalah baru seperti orang tua dari siswa normal lainnya yang keberatan dengan keberadaan siswa berkebutuhan khusus yang dianggap justru menurunkan kualitas pendidikan bagi anaknya.

\section{PENUTUP}

Aplikasi konsep differentiated assessment sangat berguna karena dapat mengakomodir berbagai kebutuhan siswa. Sudah tidak tepat lagi menerapkan alat penilaian yang sama untuk semua siswa karena mereka mempunyai kemampuan dan kebutuhan yang berbeda pula. Terutama untuk kasus siswa berkebutuhan khusus yang memilih untuk bersekolah di sekolah umum. Siswa ini memerlukan alat penilaian tersendiri mengingat mereka mempunyai kemampuan yang unik dan tidak dimiliki oleh rata-rata siswa normal. Salah satu alat untuk menilai siswa berkebutuhan khusus adalah dengan membuat program IEP. Melalui IEP, guru dan anggota tim lainnya membuat kurikulum khusus untuk siswa tersebut namun dengan tetap berbasis pada kurikulum sekolah pada umumnya. Kandungan dari IEP adalah kolaborasi antara kurikulum sekolah dengan target non akademis lainnya, disesuaikan dengan kebutuhan dan kondisi siswa. Dengan dibuatnya IEP, diharapkan siswa berkebutuhan khusus ini tetap dapat mengikuti sekolah umum meski dengan perlakuan kurikulum yang agak berbeda dengan siswa lain. Ketertinggalan siswa ini dalam hal target kurikulum sekolah akan menjadi konsekwensi yang harus dihadapi namun mereka mendapatkan banyak manfaat positif seperti belajar hidup mandiri dan bersosialisasi serta berinteraksi dengan orang lain tanpa bantuan. Tujuan akhir bagi siswa berkebutuhan khusus ini adalah mampu hidup mandiri di masyarakat dan mampu menghadapi berbagai rintangan dalam hidup mereka. Bukankah mereka juga mempunyai kesempatan yang sama layaknya siswa normal?

\section{DAFTAR PUSTAKA}

Chapman, C., \& King, R. (2005). Differentiated assessment strategy: One tool doesn't fit all. USA: Corwin Press.

Choiri, S. (2010). Latar belakang pendidikan inklusif bagi anak berkebutuhan khusus. Diakses dari http://salimchoiri.blog.uns.ac.id/2010/03/31/latar-belakang-pendidikan-inklusif-bagi-anakberkebutuhan-khusus/

Taylor, R. L., Smiley, L. R., \& Richards, S. B. (2009). Exceptional students: Preparing teachers for the 21st century. New York, USA: McGraw-Hill. 